\title{
A survey of levels of ethyl carbamate in beer sold in south-east Nigeria.
}

\author{
Onyekachi C Nwagbaoso*, Emma A Mazi, Kennedy A Okoronkwo \\ Department of Food Science and Technology, Abia State University, PMB 2000, Uturu, Abia State, Nigeria
}

\begin{abstract}
Ethyl carbamate (EC) is a carcinogen produced in alcoholic beverages during fermentation and storage. The purpose of this study was to identify and quantify ethyl carbamate in beer sold in South-East Nigeria using Gas-chromatographic method. A total of 27 beer samples were divided into three brands such as Lager, Herbal lager and Ale. Triplicate samples of each brand were obtained from three major distributors in three South-Eastern states of Nigeria. The results of the beer samples analyzed showed that ethyl carbamate occurred in high concentrations range of 0.033-0.072 $\mathrm{mg} / \mathrm{L}$ (mean $0.055 \mathrm{mg} / \mathrm{L}$ ) and thus may pose a serious health risk to humans.
\end{abstract}

Keywords: Alcoholic beverages, Ethyl carbamate, Gas chromatography, Beer, Concentration.

Accepted on June 29, 2018

\section{Introduction}

Alcoholic beverages which occur throughout the world in many forms and tastes, result from the action of microorganisms or enzymes on a wide range of agricultural products such as grapes (Vitis vinifera), soybeans (Glycine max) and grains [1]. Alcoholic beverages serve to construct "an ideal world". They constitute wine, spirits, and beer, which is the most consumed alcoholic beverage in the world [2]. Beer is a millennial alcoholic beverage that allows consumers to taste different types and styles depending on how the production process is conducted or raw materials which are used [3].

Overall, beer is a yeast fermented product of the brewer's wort obtained from malted cereals such as barley (Hordeum vulgare). They may or may not be supplemented with other cereals or sources of sugar called adjuncts, as well as with the addition of hops (Humulus lupulus) [4].

Beer is one important alcoholic beverage in Nigeria demanding investigation of the toxic content as greater percentage of the populace finds solace in this beverage. Heavy episodic rather than moderate drinking has been observed as being common among alcohol users in Nigeria as recorded by Gureje et al. [5]. The popular maxim among Nigerian women "what a man can do a woman can do it better" has seemingly extended to an increasing consumption of alcohol by the female folks, as reported by Obot [6]. Without taking cognizance of the risk of alcohol-related cancers-particularly breast cancer which even moderate alcohol intake resultantly increases as reported by Muanya [7].

Beer, whisky, fruit brandies, and wine have been found to contain quantifiable levels of ethyl carbamate which is naturally formed in fermented foods and alcoholic beverages during the fermentation process or during storage [8].

Ethyl carbamate (EC), known as urethane, is an ester of carbamic acid. It can be found in fermented foods and beverages like bread, yogurt, spirits, wine and beer [9]. It can be formed from various substances such as hydrocyanic acid found in fruit stones or through the reaction between urea and ethanol during yeast fermentation [10]. It was used as a hypnotic in man at doses of 1 gram per person per day and an anesthetic for laboratory animals in 1940s.
However, it was found to be gene toxic and carcinogenic in 1943 [11]. It is rapidly absorbed from the gastrointestinal tract and the skin and then distributed in the body [12].

In the liver, up to $90 \%$ of ethyl carbamate (EC) absorbed is hydrolyzed by microsomal esterase and eliminated as ethanol, carbon dioxide and ammonia. EC is also oxidized to vinyl carbamate $(0.5 \%)$ by cytochrome P-450, $2 \mathrm{E} 1$ and further converted into vinyl carbamate epoxide, which can bind covalently to DNA, RNA, and proteins [13]. The carcinogenic potential of EC includes gene mutations and DNA damage. Animal studies have shown that EC causes an increase in the incidence of tumors in several sites including lungs, liver, and blood vessels [14].

Human exposure to ethyl carbamate is predominant through the consumption of foods and alcoholic beverages and has raised an issue of concern over the past twenty years. This led to surveys on levels of ethyl carbamate in food and beverages being conducted, culminating in the International Agency for Research on Cancer classifying ethyl carbamate as "possibly carcinogenic to humans" in 2004 [15] and re-classifying it as "a carcinogen" in 2007 [16].

The purpose of this study was for identification and quantification of ethyl carbamate in beer sold in South-east Nigeria.

\section{Materials and Methods}

\section{Study location}

The survey was carried out in three South-eastern states (Anambra, Abia and Enugu) of Nigeria.

\section{Sample collection}

A total of 27 beer samples were purchased from three Southeastern states (Anambra, Abia and Enugu) of Nigeria where there is the presence of breweries and product availability. The samples were carefully labeled with alpha-numeric codes. Triplicate samples of 3 different commercial brands of beer $[(n=9)$ larger, herbal larger, and ale] were purchased from major distributors in three different locations of the South-eastern states.

\section{Materials}

All organic solvents used were of analytical grades and obtained from Sigma-Aldrich.

J Food Sci Nutr 2018 Volume 1 Issue 2 


\section{Apparatus}

A 7820A GC-5977E MS (Agilent Technologies, Santa Clara, CA, USA) was used for the quantification and identification of EC. The GC conditions were as follows: capillary column $30 \mathrm{~m}$ length $\times 0.25 \mathrm{~mm}$ id, $0.25 \mu \mathrm{m}$ film thickness DB-WAX (J\&W, Folsom, CA, USA), helium carrier gas at $1 \mathrm{~mL} / \mathrm{min}$, injection volume with $2 \mu \mathrm{L}$ in split less mode, and injector $210^{\circ} \mathrm{C}$. Oven temperature: $60^{\circ} \mathrm{C}, 10^{\circ} \mathrm{C} / \mathrm{min}$ to $90^{\circ} \mathrm{C}, 2^{\circ} \mathrm{C} / \mathrm{min}$ to $130^{\circ} \mathrm{C}$ held for $5 \mathrm{~min}, 20^{\circ} \mathrm{C} / \mathrm{min}$ to $220^{\circ} \mathrm{C}$, and then held for $3 \mathrm{~min}$. The MS was operated in the selected ion monitoring (SIM) with electron impact ionization $(70 \mathrm{eV})$. The MS transfer line and ion source were kept at $240^{\circ} \mathrm{C}$ and $230^{\circ} \mathrm{C}$, respectively. Mass to charge $(\mathrm{m} / \mathrm{z}) 62$ and 64 were major fragment ions of EC and d5-EC. EC was quantified using calibration curves made from peak area ratios of EC/d5-EC (m/z 62 vs. m/z 64). EC peak was identified by comparing the area ratios of $\mathrm{m} / \mathrm{z} 62$ vs. $\mathrm{m} / \mathrm{z} 74$ that were major fragment ions of EC.

\section{Preparation of standard solution}

The stock solution of Ethyl carbamate $(1000 \mu \mathrm{g} / \mathrm{mL})$ was prepared by dissolving $0.1 \mathrm{~g}$ of $\mathrm{EC}$ in acetone. A working solution $(400 \mu \mathrm{g} / \mathrm{mL})$ was made by diluting the stock solution in acetone. For spiking in the sample, internal standard was diluted in distilled water instead of acetone.
D5-EC (Deuterated ethyl carbamate) stock solution was prepared by weighing to the nearest $0.01 \mathrm{mg}, 5.0 \mathrm{mg}$ of d5-Ethyl carbamate into a $500 \mathrm{~mL}$ volumetric flask, diluted to volume in ethanol and stored at $-20^{\circ} \mathrm{C}$ protected from light.

\section{Analysis of ethyl carbamate}

Ethyl carbamate determination was carried out according to the AOAC Official method 994.07 [17]. The d5-ethyl carbamate was used as an internal standard. A $2.0 \mathrm{~g}$ beer sample containing $100 \mu \mathrm{L}, 1.0 \mu \mathrm{g} / \mathrm{mL} \mathrm{d}$ 5-ethyl carbamate was added into a centrifuge tube and vortexed for $1 \mathrm{~min}$. A diatomite solid-phase extraction column was used and the analyte was eluted from the mixture with $10 \mathrm{~mL}$ of $5 \%$ ethyl acetate after 10 min of short static stretches. The resulting eluate was collected, dried by anhydrous Sodium sulfate and concentrated using N2 flow at $30^{\circ} \mathrm{C}$. The analyte was further diluted with methanol to a final volume of $1 \mathrm{~mL}$ for MS analysis. Calibration solutions were prepared by diluting the standard solution in an ethanol/water mixture $(40 \% \mathrm{v} / \mathrm{v})$. EC was quantified using calibration curves. All samples were measured three times and the data were presented as the average of the three measured values.

\section{Statistical analysis}

Data were subjected to ANOVA and means were separated by Tukeys test using SPSS 16.0 software (Table 1).

Table 1. Concentrations of ethyl carbamate in beer sold in south-east Nigeria.

\begin{tabular}{|c|c|c|c|}
\hline Samples & Beer Brand & State & Acetaldehyde (Mg/L) \\
\hline Aa1 & Lager & Abia & $0.06 \pm 0.00^{b}$ \\
\hline Ba1 & & & $0.04 \pm 0.01^{d}$ \\
\hline Ca1 & & & $0.06 \pm 0.01^{b}$ \\
\hline Aa2 & Herbal Lager & & $0.05 \pm 0.01^{c}$ \\
\hline Ba2 & & & $0.07 \pm 0.01^{\mathrm{a}}$ \\
\hline $\mathrm{Ca} 2$ & & & $0.07 \pm 0.00^{\mathrm{a}}$ \\
\hline Aa3 & Ale & & $0.07 \pm 0.00^{\mathrm{a}}$ \\
\hline Ва3 & & & $0.04 \pm 0.00^{\mathrm{d}}$ \\
\hline $\mathrm{Ca} 3$ & & & $0.06 \pm 0.00^{\mathrm{b}}$ \\
\hline Db4 & Lager & Anambra & $0.05 \pm 0.00^{\circ}$ \\
\hline Eb4 & & & $0.07 \pm 0.01^{\mathrm{a}}$ \\
\hline $\mathrm{Fb} 4$ & & & $0.05 \pm 0.00^{c}$ \\
\hline Db5 & Herbal Lager & & $0.04 \pm 0.00^{d}$ \\
\hline Eb5 & & & $0.07 \pm 0.01^{\mathrm{a}}$ \\
\hline Fb5 & & & $0.04 \pm 0.00^{d}$ \\
\hline Db6 & Ale & & $0.06 \pm 0.00^{b}$ \\
\hline Eb6 & & & $0.06 \pm 0.01^{b}$ \\
\hline $\mathrm{Fb} 6$ & & & $0.05 \pm 0.00^{c}$ \\
\hline Gc7 & Lager & Enugu & $0.03 \pm 0.00^{e}$ \\
\hline $\mathrm{Hc} 7$ & & & $0.06 \pm 0.01^{b}$ \\
\hline Ic7 & & & $0.05 \pm 0.00^{c}$ \\
\hline Gc8 & Herbal Lager & & $0.06 \pm 0.00^{b}$ \\
\hline $\mathrm{Hc} 8$ & & & $0.06 \pm 0.01^{b}$ \\
\hline Ic8 & & & $0.06 \pm 0.00^{\mathrm{b}}$ \\
\hline Gc9 & Ale & & $0.06 \pm 0.00^{b}$ \\
\hline $\mathrm{Hc9}$ & & & $0.05 \pm 0.01^{c}$ \\
\hline Ic9 & & & $0.06 \pm 0.00^{b}$ \\
\hline
\end{tabular}

International maximum limit $0.005 \mathrm{mg} / \mathrm{L}$ (EFSA, 2007)

Results are Mean \pm standard deviation of 3 determinations. Means in the same column with different superscripts are significantly different $(p<0.05$ ).

$\mathrm{Aa} 1, \mathrm{Ba} 1$ and $\mathrm{Ca} 1=$ Lager from distributors in Abia

$\mathrm{Aa} 2, \mathrm{Ba} 2$ and $\mathrm{Ca} 2=$ Herbal lager from distributors in Abia

$\mathrm{Aa} 3, \mathrm{Ba} 3$ and $\mathrm{Ca} 3=$ Ale from distributors in Abia

$\mathrm{Db} 4, \mathrm{~Eb} 4$ and $\mathrm{Fb} 4=$ Lager from distributors in Anambra

$\mathrm{Db} 5, \mathrm{~Eb} 5$ and $\mathrm{Fb} 5=$ Herbal lager from distributors in Anambra
Db6, Eb6 and Fb6 = Ale from distributors in Anambra

Gc7, Hc7 and Ic7 = Lager from distributors in Enugu

$\mathrm{Gc} 8, \mathrm{Hc} 8$ and Ic8 = Herbal lager from distributors in Enugu

Gc9, Hc9 and Ic9 = Ale from distributors in Enugu 


\section{Results and Discussion}

Ethyl carbamate is naturally formed in fermented foods and alcoholic beverages during the fermentation process and/or during storage. The concentrations of ethyl carbamate (EC) in the selected alcoholic beverages (beer) analyzed by gas chromatography/mass spectrometry (GC/MS) are presented in Table 1. The concentrations of ethyl carbamate in the beer samples ranged from $0.03-0.07 \mathrm{mg} / \mathrm{L}$. The content of ethyl carbamate is higher than the range of $0.0006-0.005 \mathrm{mg} / \mathrm{L}$ and $0-0.0058 \mathrm{mg} / \mathrm{L}$ reportedly found in beer samples from Hong Kong by CFS [17] and Zhao et al. [18], respectively. Additionally, the incidence of ethyl carbamate in the beer samples analyzed in this study was higher than the range of $0.002 \mathrm{mg} / \mathrm{L}$ and $0.003 \mathrm{mg} / \mathrm{L}$ found in 20 beer samples from China as reported by Wu et al. [19] and higher than the concentration range of $0-0.001 \mathrm{mg} / \mathrm{L}$ reportedly found in 13 beer samples analyzed in European Union by EFSA [20].

The ethyl carbamate concentrations presented in Table 1 were above the Canadian limit of $0.015 \mathrm{mg} / \mathrm{L}$ for regular beer $[21,22]$ and the SAQ limit of $0.03 \mathrm{mg} / \mathrm{L}$ for strong and extrastrong beer [23]. High levels of ethyl carbamate were found in the beer samples analyzed, comparatively to international maximum limits of allowance of $0.015 \mathrm{mg} / \mathrm{L}$ [24] for alcoholic beverages and available literature on beer samples analyzed in overseas countries. This includes two studies that evaluated samples of beer which contained relatively low concentrations of ethyl carbamate within the range of ND-0.005 mg/L [18,25]; the evaluation of Danish beer with very low concentrations of ethyl carbamate with a range of 0.0002-0.0066 mg/L [26] and two studies on the evaluation of Korean beer in which the concentration ranges were $0.0005-0.0008 \mathrm{mg} / \mathrm{L}$ [11] and $0.00033-0.0008 \mathrm{mg} / \mathrm{L}$ [27]. It was also higher than the range of $0.00051-0.00077 \mathrm{mg} / \mathrm{L}$ for beer samples in Korea reported by Noh et al. [27] and the concentration value of $0.0001 \mathrm{mg} / \mathrm{L}$ reported by Battaglia et al. [28].

The concentration values of ethyl carbamate shown in Table 1 were comparatively higher than the value of $<0.03 \mathrm{mg} / \mathrm{L}$ reported from the analysis of several different light to strong beer from 23 different countries but similar to one sample from Belgium $(0.033 \mathrm{mg} / \mathrm{L})$ which slightly exceeded the level of $0.03 \mathrm{mg} / \mathrm{L}[29,30]$. The evidence of ethyl carbamate in various samples provided by the literature data above indicates that ethyl carbamate is the main ester component of beer. Considering that alcoholic beverages, more especially beer are usually consumed frequently and in large amounts in Nigeria (beer $8 \%$, wine $0.4 \%$, spirit $0.9 \%$ ) according to $\mathrm{WHO}$ data on pure alcohol per capita consumption per year [31], they would likely be a cause of significant health concern for the general population.

There is a close similarity in the values of ethyl carbamate for lager beer (A1, C1) and ale (C3) from Abia, ale from Anambra (D6, E6), larger (H7), herbal larger (G8, H8, I8) and ale (G9, I9) from Enugu [32]. This could be as a result of similarities in storage conditions and climatic temperatures as samples unduly exposed to heat or light can induce ethyl carbamate formation [33]. A small range of ethyl carbamate concentration was measured among individual samples of each beer brand tested. The small variation could be as a result of similarities in precursors used, fermentation methods employed or storage conditions [34].

\section{Statistical analysis}

A one-way analysis of variance was conducted to evaluate the null hypothesis that there is no difference between the concentrations of ethyl carbamate in the commercial beer brands sold in three southeastern states of Nigeria. The samples were divided into groups according to the beer brands (lager $=9$, herbal lager $=9$ and ale=9). There was a statistically significant difference at the $p<0.000$ level in the ethyl carbamate concentrations of the three commercial beer brands, having tested and found tenable the assumption of homogeneity of variance, [Lager $\mathrm{F}(8,18)=172.885, \mathrm{p}<0.000$; Herbal lager $\mathrm{F}(8,18)=39.041$, $\mathrm{p}<0.0000$; Ale $\mathrm{F}(8,18)=42.638, \mathrm{p}<0.000]$. Despite reaching a statistical significance, the actual difference in mean scores between the beer brands was quite small. Post-hoc comparisons using the Tukey HSD test indicated that the mean score for ethyl carbamate in lager $(\mathrm{M}=0.052, \mathrm{SD}=0.011)$ was significantly different from herbal lager $(\mathrm{M}=0.055, \mathrm{SD}=0.008)$. There was also a statistical difference in mean between herbal lager and ale. The output of the ANOVA analysis showed that the significance value is 0.00 (i.e., $\mathrm{P}=0.000$ ), which is below 0.05 . Thus, there is significant evidence to reject the null hypothesis and conclude there is a statistically significant difference between the concentrations of ethyl carbamate observed in the different samples of the selected beer brands analyzed in each of the southeastern states (Abia, Anambra and Enugu) as determined by one-way ANOVA.

\section{Conclusion}

Ethyl carbamate is currently one of the biggest challenges in the alcoholic beverages industry because of its toxicity, carcinogenicity, and universality. The results of this study show that the different commercial beer brands sold in South-east Nigeria are not completely free from ethyl carbamate but also present at high concentration levels which may pose serious health risk to humans.

\section{References}

1. Smith EY. Introduction to Biotechnology. Academic press, New York, (1stedn), 1996;185-6.

2. Nelson M. The Babarian's Beverage: A History of Beer in Ancient Europe Abingdon. Oxon: Routledge. 2005;225.

3. Thiago RM, Pedro PM, Eliana FC. Solid waste in brewing process: A review. Journal of Brewing and Distilling. 2014;5(1):1-9.

4. Tschope EC. Microbreweries and breweries: History, art and technology, Editora Aden, Sao Paulo 2001.

5. Gureje O, Degenhardt L, Olley B, et al. A descriptive epidemiology of substance use and substance use disorders in Nigeria during the early 21st century. Drug Alcohol Depend. 2007;91(1):1-9.

6. Obot IS. Alcohol use and related problems in sub-Saharan Africa. African Journal of Drug and Alcohol Studies. 2006;5(1):17-26.

7. Muanya C. Even moderate alcohol intake increases cancer risk. The Guardian. 2015;5:10.

J Food Sci Nutr 2018 Volume 1 Issue 2 
Citation: Nwagbaoso OC, Mazi EA, Okoronkwo KA. A survey of levels of ethyl carbamate in beer sold in south-east Nigeria. J Food Sci Nutr. 2018;1(2):13-16.

8. Iwouno JO, Igwe V. Prevalence of ethyl carbamate in spirits from different sources. African Journal of Food Science and Technology. 2013:4(2):25-28.

9. Osobamiro T. Analysis of Some Contaminants Commonly Found in Alcoholic Beverages. American-Eurasian Journal of Scientific Research. 2013;8(1):53-6

10. Nettleship A, Henshaw PS, Meye HL. Induction of Pulmonary Tumors in Mice with Ethyl Carbamate (Urethane). Journal of National Cancer Institute. $1943 ; 4(3): 309-19$

11. Zimmerli B, Schlatter J. Ethyl Carbamate: Analytical methodology, occurrence, formation, biological activity and risk assessment. Mutat Res. 1991;259(3-4):325-50.

12. Mirvish SS. The Catabolism of Urethane and N-hydroxyurethan. Adv Cancer Res. 1968;11:1-42.

13. Beland FA, Benson RW, Mellick PW, et al. Effect of ethanol on the tumorigenicity of urethane (ethylcarbamate) in B6C3F1 mice. Food Chem Toxicol. 2005;43(1):1-19.

14. JECFA Summary and conclusions of the sixty-fourth meeting of the Joint FAO/WHO Expert Committee on Food Additives, 2005.

15. IARC Alcohol consumption and ethyl carbamate (urethane) International Agency for Research. Geneva: World Health Organization. 2010;96.

16. AOAC Association of Official Analytical Chemists official method 99407: ethyl carbonate in alcoholic beverages and soy sauce In Association of official analytical chemists, AOAC official methods of analysis, (17thedn), 2000;14-5.

17. CFS Centre for Food Safety Ethyl Carbamate in Local Fermented Foods Risk Assessment Studies Report, No 39 Hong Kong, 2009.

18. Zhaoa X, Guocheng D, Huijun Z, et al. Progress in preventing the accumulation of ethyl carbamate in alcoholic beverages. Trends in Food Science \& Technology. 2013;32:97-107.

19. Wu H, Chen L, Pan G, et al. Study on the changing concentration of ethyl carbamate in yellow rice wine during production and storage by gas chromatography/mass spectrometry. Eur Food Res Technol. 2012;235(5):779-82.

20. EFSA European Food Safety Authority. Ethyl carbamate and hydrocyanic acid in food and beverages Scientific Opinion of the Panel on Contaminants. The EFSA Journal. 2007;551:1-44

21. Canada Dept of the Environment, Dept of Health. Final Screening Assessment Report for the Substance Groupings Initiative, Carbamic acid, ethyl ester (Ethyl carbamate), Chemical Abstracts Service Registry Number (CAS RN). 2016;51:79-6.

22. SAQ (Société des alcools du Québec) Guide Standards - Constitution and Stability, last update July 31, 2014 Accessed, Dec 5, 2014.

23. Lachenmeier DK, Kanteres F, Thomas K, et al. Ethyl Carbamate in Alcoholic Beverages from Mexico (Tequila,
Mezcal, Bacanora, Sotol) and Guatemala (Cuxa): Market Survey and Risk Assessment. Int J Environ Res Public Health. 2009;6:349-60.

24. FAO/WHO (Food and Agriculture Organization of the United Nations/World Health Organization). Safety evaluation of certain contaminants in food. Food Nutr Pap. 2006;82:1-778.

25. Vahl MA. Survey of ethyl carbamate in beverages, bread and acidified milks sold in Denmark. Food Addit Contam 1993;10(5):585-92.

26. Ha MS, Ki-Sung K, Meehye K, et al. Exposure assessment of ethyl carbamate in alcoholic beverages. J Microbiol Biotechnol. 2006b;16(3):480-3.

27. Noh IW, Ha MS, Han EM, et al. Assessment of the human risk by an intake of ethyl carbamate present in major Korean fermented foods. J Microbiol Biotechnol. 2006;16(12):1961-7.

28. Battagalia R, Conacher HB, Page BD. Ethyl carbamate (Urethane) in alcoholic beverages and food. Food Addit Contam. 1990;7(4):477-96.

29. FSC Food Safety Commission Evaluation Report of Food Additives: Acetaldehyde. Japan 2005.

30. WHO World Health Organization Fourth Global Status report on Alcohol and health with data from 2010-2014.

31. Ha MS, Hu SJ, Park HR. Estimation of Korean adult's daily intake of ethyl carbamate through Korean commercial alcoholic beverages based on the monitoring. Food Sci Biotechnol. 2006a;15:112-6.

32. Henschke PA, Jiranek V. Yeasts-metabolism of nitrogen compounds in Wine Microbiology and Biotechnology (Fleet, GH Ed) Harwood Academic Publishers; Amsterdam, Germany. 1993;77-164.

33. Ian SH. A History of Beer and Brewing. Royal Society of Chemistry. 2003;34:742.

34. Secretan B, Straif K, Baan R, et al. A review of human carcinogens - Part E: tobacco, areca nut, alcohol, coal smoke, and salted fish. Lancet Oncol. 2009;10:1033-4.

\section{*Correspondence to:}

Onyekachi C Nwagbaoso

Department of Food Science and Technology

Abia State University

Abia State

Nigeria

E-mail: nwagbaosoonyekachi@yahoo.com 